\title{
Mapping the Social Space of Opinion: Public Sociology AND the Op-Ed IN CANADA $^{1}$
}

\author{
LiSA KowalchuK \\ NeIL McLaughlin
}

\begin{abstract}
Op-eds in newspapers represent an important form of intellectual debate that helps shape public opinion and elite policy. For academics, writing op-eds offers an opportunity to publicize a book or other research findings, and to gain influence and attention for their ideas. Given a reward structure within the academy that stresses peer review publication, professors are at a decided structural disadvantage, compared to journalists, when they try to enter the oped space. Thus op-eds give us a useful window into how academics and public sociologists enter the public sphere in comparison to columnists, think-tanks, politicians, social movement activists, and corporate leaders. Drawing on the innovative theoretical approach outlined by Ronald Jacobs and Eleanor Townsley, this paper offers an analysis of a selected set of Canadian op-eds and suggests a research agenda for studying op-eds in Canada. Not surprisingly, we find that journalists dominate the space of the op-ed in Canada. We also find that sociologists are fairly underrepresented compared to our obvious competitors in the social sciences. We conclude with thoughts about the implications of our findings for further research in the sociology of sociology, public sociology and the study of the social space of opinion. We also offer informed suggestions regarding normative and practical issues that Canadian sociologists should consider in light of these broader empirical patterns.
\end{abstract}

Keywords: Op-eds, social space of opinion, media studies, Canadian public sociology

Résumé. Les articles publiés dans les pages d'opinion de la presse écrite (Op-Ed) sont une forme importante de débat intellectuel. Ils participent à la formation de l'opinion publique et la politique des élites. Pour le milieu académique, les

1. This research was made possible through a grant from the Social Sciences and Humanities Research Council of Canada (SSHRC). The authors would also like to thank student research assistants Tegan Ceschi-Smith and Terrence Hamilton for their work in the project, and the University of Guelph's Undergraduate Research Assistant (URA) program. We are also grateful to the $C J S$ reviewers for their insightful comments. 
Op-Ed offrent la possibilité de rendre public un livre ou des résultats de recherche. Cela permet également de gagner en influence et d'attirer l'attention sur ses idées. Mais, la structure de valorisation propre au milieu académique favorise avant tout la diffusion des résultats par évaluation des pairs. Dès lors, d'un point de vue structurel, les professeurs sont clairement désavantagés par rapport aux journalistes lorsqu'ils tentent de participer au monde des Op-Ed. Ainsi, les Op-Ed offrent une perspective utile sur la manière dont le milieu académique et les sociologues publiques participent à la sphère publique. Cette perspective permet de comparer le milieu académique avec les éditorialistes, les groupes de réflexion, les politiciens, les activistes des mouvements sociaux et les leaders du monde corporatif. En se basant sur l'approche théorique innovante proposée par Ronald Jacobs et Eleanor Townsley, cet article analyse et propose un programme de recherche sur les Op-Ed au Canada. Sans grande surprise, nous avons trouvé que les journalistes sont les plus présents dans les Op-Ed. Nous avons également trouvé que les sociologues sont plutôt sous-représentés par rapport à nos concurrents évidents des sciences sociales. En conclusion, nous réfléchissons aux implications de nos résultats pour de futures recherches en sociologie de la sociologie et en sociologie publique ainsi que pour l'étude de l'espace social de l'opinion. Nous partageons également des suggestions pour les enjeux normatifs et pratiques que les sociologues canadiens doivent considérer en lumière de ces larges modèles empiriques.

Mots clés: Op-Eds, l'espace social de l'opinion, études de medias, sociologie publique canadien

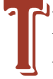
his special issue of $C J S$ illustrates the international spread of an empassioned debate among sociologists about the future direction of their discipline ignited by Michael Burawoy's call to elevate the presence and status of public sociology. Burawoy's program entails a greater engagement by sociologists with civil society (nongovernmental organizations, communities, movements) in the development of their research agenda, and the production of research outputs that are more accessible, relevant, and useful to nonacademic audiences. Burawoy and his supporters see the emphasis on public sociology as a way to revitalize the discipline, in particular, to solve several interrelated problems that it faces, at least in the US: a lack of internal coherence, declining public legitimacy, public misapprehension of what sociologists do, and minimal influence on policymaking (Burawoy 2004a; Turner 2006; Boyns and Fletcher 2005). Skeptics and critics within the discipline, conversely, argue that "going public" will only hurt sociology's public legitimacy, insofar as it constitutes a kind of left-liberal moralizing that is out of sync with majority currents of opinion.

In our view, normative debates about the role of public sociology in Canada are best undertaken with reference to empirical research on the actual state of the discipline's engagement in, and dialogue with, 
the public through a variety of specific forums (McLaughlin et al. 2006; McLaughlin and Turcotte 2007). In other words, the issue of whether sociologists should do more public academic work in Canada begs the question of what place sociology actually occupies in the broader contemporary space of public opinion and debate. ${ }^{2}$ Burawoy's program presumes the existence of a deficit in public forms of intellectual labour on the part of sociologists compared to other social scientists. Whether or not this is true in Canada is the empirical question that we address by looking at one particular form of public intellectual work by sociologists, namely opinion pieces in Canadian newspapers.

The debate sparked by Burawoy (2005a; 2005b; 2005c; 2005d) has largely focused on the politics of public sociology, the consequences of this proposed direction for the discipline's academic legitimacy and intellectual project and, more recently, comparative questions as the debate spreads to the European Union, Russia, and Latin America and the global South. We have also seen a number of semi-autobiographical pieces that stress the personal experiences of various proponents and practitioners of public sociology. We believe that the debate requires a new focus on the dynamics of specific genres of public sociological work. Scholars can take their ideas outside scholarly journals and the classroom in several ways, including TV appearances, popular books, public lectures and speeches and, in our contemporary wired world, blogs and web-pages. One of the most common versions of public sociology has long been the opinion piece in newspapers, a short 700-800 word essay published opposite the editorial page in most broadsheet and tabloid papers in North America. With this in mind, we look specifically at op-ed writing in Canada, with an eye towards clarifying the sociological contours of this form of contributing to public debate.

As the first study of the "space" of the op-ed in Canada, our paper emphasizes questions about the role sociologists play in this form of intellectual activity compared to other major opinion makers who operate in the journalistic, political, and academic fields. In mapping this space, we were guided by several questions. What role do sociologists in Canada play in this form of intellectual dialogue and debate? What role do

2. We leave aside, for now, the complex question of the relationship between public academics and public intellectuals, in Canada and more generally. For an excellent discussion of the concept of the public intellectual, see Townsley (2005). For intellectuals in Canada, see Gagnon (1987), Brym and Myles (1989), Massolin (2001). Neil McLaughlin is working on an essay with Townsley entitled the "The public intellectual debate in Canada" that will clarify some of the differences between public intellectuals and public academics, as well as discussing some US and Canadian comparisons. Collini's Absent Minds (2006) is essential reading for discussing the notion and the history of the public intellectual. 
academics from other disciplines play? How is this genre of writing to be understood theoretically?

Burawoy actually says very little about op-eds per se, partly, we suspect, because of his view that op-ed writing is an elite form of "traditional" public sociology that is geared to "thin" publics, seeks the limelight, and addresses the public interest as conceived of in general terms. Traditional public sociology, according to Burawoy, reaches, " a wide but thin audience and would include books that stimulate reflexive debate ... or columns in national newspapers such as the New York Times." This form of public sociology is traditional, for Burawoy because

it formulates a common public 'interest' and it does so at arm's length, in contrast to an organic or grassroots public sociology that engages the particularistic interests of more circumscribed publics - neighbourhood groups, communities of faith, labour organizations, and so on. (Burawoy 2004a:5-6, emphasis in original)

In this statement Burawoy is only considering op-eds in major national newspapers, and we think one cannot fully understand the op-ed space without taking regional and local papers into account. Any effort to distinguish between traditional and organic forms of op-ed writing would require, furthermore, a close examination of the actual texts, a sociological analysis of the relationship of specific authors to various publics, and even an analysis of the "reflexive" (or not!) reception of texts, a range of issues we have not attempted to address in this preliminary analysis. ${ }^{3}$ More generally, we believe Burawoy's project requires further emphasis, not so much on individual sociologists and where they fit in his $2 \times 2$ matrix (the focus in Burawoy's address in Barcelona in August 2008 at the International Sociological Association Forum on public sociology), but on different genres of public sociology. ${ }^{4}$

In this paper we offer an analysis of a selected set of Canadian op-eds and suggest a research agenda for studying op-eds in Canada. We begin

3. We leave aside for now a discussion of the concepts of "organic" and "traditional" intellectuals and Burawoy's reliance on Gramscian notions developed in a rather different historical context. Another aspect of Buroway's typology that needs to be conceptualized more clearly is the distinction between thick and thin publics, something that we will not be attempting here.

4. For Burawoy (see for example 2004b), public sociology is one of four complementary types of sociological labour, each defined according to the type of audience to which it is directed (academic vs. nonacademic) and the type of knowledge it generates (instrumental vs. reflexive). Both public and critical sociology are reflexive in their subject of inquiry, that is, they are guided by ethical questions about society, but differ in that public sociology addresses nonacademic audiences. Both professional and policy sociology lie on the instrumental side of the knowledge axis in that they are geared to solving problems or puzzles, but the latter is conducted on a contractual basis for a client or sponsor outside of academe, such as a government bureaucracy or an NGO. 
by outlining our sampling and data-gathering strategy in our methods section, and then describe our findings regarding where sociologists fit in the space of op-ed writing in Canadian newspapers compared to other intellectuals who attempt to shape public opinion through this genre. We conclude with thoughts about the implications of our findings for further research in the sociology of sociology and the study of the social space of opinion, also offering informed suggestions regarding normative and practical issues that Canadian sociologists should consider in light of these broader empirical patterns.

\section{Studying and Mapping the Social Space of Canadian Opinion}

Drawing from the pioneering research agenda of American sociologists Eleanor Townsley and Ronald Jacobs (Jacobs and Townsley 2004; Jacobs and Townsley forthcoming), we regard op-eds as a useful entry point into the study of the public sphere and public sociology. There are several studies that use data on op-eds to answer larger questions (Nikolaev and Porpora 2007; Yagcioglu and Cem-Deger 2001), some of them involving Canadian data (Winter 2007). Jacobs and Townsley (2004) have written about the topic in the United States and will be publishing the definitive work on the topic in their book Media Intellectuals and the Social Space of Opinion (forthcoming). ${ }^{5}$ But no major study has looked at op-eds in Canada as a topic for sociological analysis, despite the fact that they are one of the more common means by which academics, journalists, and other intellectuals attempt to shape public opinion on a mass scale.

When established or junior sociologists in Canada decide to step out of the ivory tower to engage the public, op-eds are an obvious option. Sociologists interested in reaching the pubic by writing op-eds, however, face a series of obstacles and challenges, not least of all competition from journalists, think-tank staff, politicians, and academics in other disciplines. Thinking sociologically about the nature of this particular space of opinion formation in the Canadian context is, for us, an im-

5. We owe the basic theoretical framework for this paper to Jacobs and Townsley, and have been working with them on comparative research on the Canadian versus the American space of social opinion. Their theoretical frame is powerful and innovative, combining elements of Bourdieu's field analysis, Jeffrey Alexander's strong program in the sociology of culture, and their own theoretical contributions to the sociology of the media and intellectuals, respectively. For example, see Jacobs (2009) and Townsley (2005). Their forthcoming co-authored book, which deals with a range of genres beyond op-eds such as TV political talk shows, could provide a model for comparative research in the Canadian context. For Bourdieu's field theory as applied to journalism, see Bourdieu (2005). For a provocative discussion of Bourdieu in his public sociology stage, see Swartz (2000). 
portant precondition for asking useful empirical questions about public sociology.

An analysis of op-eds in contemporary newspapers also represents an entry point to the interaction, as well as intellectual and professional competition, between academics and journalists in modern society (Jacobs and Townsley 2004). Both academia and journalism are organized around a deep division between fact and values (Jacobs and Townsley 2004). Newspapers in the 18th and 19th centuries were extremely partisan and politically motivated organs, where the emergence of modern journalistic practices encourages the ideal - if not the reality - of purely factual reporting (Schudson 1978; Starr 2004). This larger context explains why the editorial and op-ed pages emerged as a specific space in newspapers where opinions could be expressed, without jeopardizing the unbiased image of a paper oriented towards "news" rather than propaganda or political pamphleteering. As the modern newspaper developed, the owners of the press would publish their views, political endorsements, and opinions on the editorial pages, leaving the space opposite their interventions to three or four opinions written by columnists, politicians and, importantly for our purposes, the occasional academic. The spatial separation of "fact" and "opinion" in the very layout of the newspaper reflected the new ideology of professional journalism in mainstream media, particularly in the United States (Jacobs and Townsley forthcoming). Canadian journalism generally followed the lead of the American, as well as the British and French model (Schiller 1981; Schudson 1978; 2005; Starr 2004).

Academics are, of course, at a decided structural disadvantage when they try to enter into the op-ed space. This is partly because academia, like journalism, is organized around a fact and value division (Jacobs and Townsley 2004). The elite within the journalistic field are columnists who are elite precisely because they are paid to write their opinions on issues of their choosing. In contrast, the reward structure of the academy is organized around peer-reviewed publications, teaching, and university administration; nonacademic writing is not formally emphasized as a valued intellectual activity. It is true that op-eds in high-prestige venues tend to gain status and attention for intellectuals, including academics (Coser 1965). Moreover, university public relations offices want media attention for their faculty, provided this does not involve excessive controversy or scandal. There are a number of reasons for academics to write op-eds, motivations sometimes linked to professional careers: publicity for a book, the promotion of research findings that have policy implications, and a general desire to gain influence and attention for one's ideas. Nonetheless, the very logic of the academic field runs in the opposite 
direction, stressing peer-reviewed scholarship and the battle for status within restricted audiences in the academic field (Clemens et al. 1995; Coser et al. 1982; Nock 1999; 2000).

It is sometimes suggested that academics possess far fewer skills for influencing media discourse than other media-oriented actors such as PR firms, politicians, journalists, marketers, and the like, and, furthermore, that sociologists are even less media-savvy than other social scientists. It is likely, furthermore, that the quick pace of op-ed writing and the need to restrict discussion of theory and methods and limit word counts, makes it difficult for most academics to write regular op-eds. Overall, the space of the op-ed is one controlled and dominated by actors rooted in the journalistic field since this is clearly their professional home-turf. Nonetheless, with a large enough sample of op-eds it is possible to study both academics' place within this form of opinion generation, and how professors' contributions to the op-ed pages vary according to discipline, type of university, and other traits. While analyzing op-eds may point to patterns of professional competition between journalists and academics, it is the latter group's op-ed writing that is our primary concern here. Hence we have little to say about the regular newspaper columnists and their contributions to the op-ed pages, and instead focus on academics in general, and sociologists, in particular, as op-ed writers.

What kinds of empirical questions, then, are prompted by this theoretical framework? Is our argument about the differences between the academic and journalistic fields supported by evidence from the realm of oped writing? While we would certainly expect academics to be outnumbered by regular news columnists, how large a gap is there between these different professional groups, and how do journalists and columnists compare to other occupational groups, such as think-tank professionals, business leaders, politicians, etc? To what extent is the op-ed space opening up to contributors from nonjournalistic backgrounds now that funding sources in Canada push academics to do more policy-relevant research? Are there differences between the types of newspapers and the regions in Canada with regards to patterns in op-ed writing? Do scholars from Canada's elite universities dominate op-ed writing or is there a more egalitarian institutional pattern, as suggested by some scholars and commentaries on the Canadian academic field (Davies and Hammack 2005; McLaughlin 2005)?

Our study also explores how these outcomes vary with the scope (national vs. local) and, to some extent, the ideology of the newspaper, as well as the research versus teaching focus of the institution in which academic authors are located. With the public sociology debate in mind, how often do sociologists write op-eds relative to columnists, journalists, 
think-tank scholars, activists, and politicians? How often do sociologists appear, compared to their colleagues in other disciplines in and outside of the social sciences? The debate about public sociology in Canada will, we believe, be far more productive and useful if we ground our discussions with a broad and empirically based map of the general social space of opinion in our particular national context (Jacobs and Townsley forthcoming), something we outline in our empirical analysis below.

\section{Methods}

Our sample consists of op-eds published during the most recent full year of online newspapers available when we began the research (2005) and during an additional full year five years earlier, giving us data from the years 2004 and 1999. Ideally we would trace changes over time in the social space of opinion by obtaining a longitudinal sample from Canadian newspapers, and we intend to follow this research with more than two points of time in the late 20th and early 21 st century. Here we chose 2004 as the most recent national election year (Canada's 38th federal election) and 1999, when there was no national election. ${ }^{6}$ Following Jacobs and Townsley, we note that national elections are likely to shape, in significant ways, the content of op-ed writing and the composition (particularly disciplinary origin) of op-ed authors, precisely the issues we are studying. This tendency is probably less pronounced in Canada than in the US because of our relatively short election cycle, and the less public nature of leadership struggles within major parties (we do not have American-style primaries), but we chose our sample partly with these issues in mind.

We selected newspapers with a view to providing some representation of the east and west coasts, the prairies, Ontario, and Quebec. Our sampling of the newspapers themselves was based partly on convenience, since we included only those Canadian news dailies whose online archives could be accessed via the university libraries of Guelph, McMaster, and the University of Western Ontario. Within each region, we chose one or two of the larger circulation dailies. For Quebec, we chose the main English-language newspaper, The Montreal Gazette, as well as the French-language Le Devoir. From the point of view of Quebec as a nation within a nation, Le Devoir is widely regarded as the province's "national" newspaper. The choice of the Globe and Mail and the $\mathrm{Na}$ tional Post ensured that Canada's two self-styled "national" papers were represented. As well, these two papers give voice to both the elite central Canadian establishment, and a new ideologically conservative perspec-

6. Provincial elections would likely have an effect on the rates of op-ed writing by political scientists in the regional newspapers, but it was too complex to factor in all the variables. 
tive in the national scene. To capture possible differences between the newspapers in medium-sized university towns, we included the Kitchener Record and Guelph Mercury.

To select op-eds within each newspaper we used a systematic random sampling technique (Riffe et al. 1998; Neuman 2006), collecting all the op-eds published every tenth day for 1999 and 2004. ${ }^{7}$ Several newspapers in the sample, including the National Post and the Globe and Mail, have three or four op-eds each day, while papers like the Edmonton Journal and Kitchener Record tend to publish only one or two op-eds per issue. Of the total sample of 2215 op-eds (1999 and 2004 combined), the papers with the highest proportion of op-eds are the National Post (13\%), the Vancouver Sun (12\%), the Globe and Mail (11\%), and the Toronto Star (10\%). For the purpose of mapping the social space of oped writing in Canadian newspapers, items in the sample were coded for authors' gender, national and provincial base, occupation, and, for those who were university professors, institution and discipline or program.

Table 1: Distribution of Op-eds by Newspaper, 1999 and 2004 Samples Combined ${ }^{1}$

\begin{tabular}{lcc}
\multicolumn{1}{c}{ Newspaper } & Frequency & Percent \\
National Post & 286 & 12.9 \\
Vancouver Sun & 265 & 12.0 \\
Globe and Mail & 246 & 11.1 \\
Montreal Gazette & 244 & 11.0 \\
Toronto Star & 221 & 10.0 \\
Winnipeg Free Press & 211 & 9.5 \\
Calgary Herald & 209 & 9.4 \\
Guelph Mercury & 185 & 8.4 \\
Edmonton Journal & 142 & 6.4 \\
Le Devoir & 83 & 3.7 \\
Kitchener Record & 74 & 3.3 \\
Halifax Chronicle-Herald & 49 & 2.2 \\
Total & 2215 & 100.0 \\
\hline 1. Le Devir
\end{tabular}

1. Le Devoir and the Halifax Chronicle-Herald were not searchable in the second period of our study. We left the papers in our sample, since they represent both linguistic and regional diversity.

\section{Results AND Discussion}

Our analysis of the op-ed writers' occupations ${ }^{8}$ reveals that, as anticipated, journalists, columnists, and broadcasters dominate the op-ed space in

7. If no paper appeared on the tenth day, or if there was no op-ed in that issue, we took our sample from the next available issue that had op-eds.

8. When more than one occupation or role was stated, we coded the first stated occupation unless the op-ed was clearly written from the perspective of the second or third role. For multiple authors, we coded only the first author since the process becomes excessively complex otherwise. We are grateful to Eleanor Townsley for her advice on occupation coding. 
these newspapers, accounting for almost two-thirds of the sample. The percentage of journalists is almost eight times that of university professors (we bolded the data on professors, for emphasis), a group that constitutes the next largest occupational group (see Table 2).

\section{Table 2: Op-ed Authors' Occupation in 12 Canadian Newspapers}

\section{Occupation}

Journalists, columnists, broadcasters

\section{Professors}

Think tank, advocacy, union

Politicians and diplomats

Writers and artists

Managers (public and private sector)

Professionals

Nonprofessional employees

Consultants

Nonoccupational role

School and college teachers

Student

Other

Total

$\begin{array}{rc}\text { Frequency } & \text { Percent } \\ 1438 & 64.9 \\ \mathbf{1 7 4} & \mathbf{7 . 9} \\ 157 & 7.1 \\ 97 & 4.4 \\ 87 & 3.9 \\ 63 & 2.8 \\ 58 & 2.6 \\ 23 & 1.0 \\ 22 & 1.0 \\ 22 & 1.0 \\ 17 & 0.8 \\ 11 & 0.5 \\ 46 & 2.1 \\ 2215 & 100.0\end{array}$

The relative proportion of op-ed writers' occupations varies somewhat depending on the newspaper. It is beyond the scope of this article to fully probe and analyze the impact of circulation, ownership, ideology, or other newspaper characteristics on the likelihood of particular occupational or academic perspectives appearing in the op-ed pages. A few patterns found in the two national English language newspapers as well as Canada's major French language daily, however, are worth noting (see Table 3).

Table 3: Newspaper by Collapsed Occupation of Op-ed Author

\begin{tabular}{|c|c|c|c|c|c|c|}
\hline & $\begin{array}{c}\text { Globe and } \\
\text { Mail } \\
\text { National Post }\end{array}$ & Le Devoir & $\begin{array}{l}\text { Kitchener } \\
\text { and Guelph }\end{array}$ & $\begin{array}{c}\text { Montreal } \\
\text { Gazette }\end{array}$ & $\begin{array}{l}\text { Large- } \\
\text { city } \mathrm{Pa}- \\
\text { pers }\end{array}$ & Total \\
\hline \multirow{2}{*}{ Journalists } & 341 & 25 & 121 & 163 & 788 & \multirow{2}{*}{$\begin{array}{r}1438 \\
66.8 \%\end{array}$} \\
\hline & $66 \%$ & $31.2 \%$ & $48.2 \%$ & $69.7 \%$ & $73.2 \%$ & \\
\hline \multirow{2}{*}{$\begin{array}{l}\text { Think tank, } \\
\text { advocacy, } \\
\text { union }\end{array}$} & 38 & 8 & 12 & 14 & 85 & \multirow{2}{*}{$\begin{array}{r}157 \\
7.3 \%\end{array}$} \\
\hline & $7.4 \%$ & $10.0 \%$ & $4.8 \%$ & $6.0 \%$ & $7.9 \%$ & \\
\hline \multirow{2}{*}{ Professors } & 57 & 22 & 9 & 25 & 60 & \multirow{2}{*}{$\begin{array}{l}173 \\
8.0 \%\end{array}$} \\
\hline & $11.1 \%$ & $27.5 \%$ & $3.6 \%$ & $10.7 \%$ & $5.6 \%$ & \\
\hline \multirow{2}{*}{ All others ${ }^{1}$} & 76 & 25 & 109 & 32 & 143 & \multirow{2}{*}{$\begin{array}{l}385 \\
17.9 \%\end{array}$} \\
\hline & $14.8 \%$ & $31.2 \%$ & $43.4 \%$ & $13.7 \%$ & $13.3 \%$ & \\
\hline \multirow{2}{*}{ Total } & 512 & 80 & 251 & 234 & 1076 & \multirow{2}{*}{$\begin{array}{l}2153 \\
100.0 \%\end{array}$} \\
\hline & $100.0 \%$ & $100.0 \%$ & $100.0 \%$ & $100.0 \%$ & $100.0 \%$ & \\
\hline
\end{tabular}

1. "All others" consists of politicians and diplomats; public and private sector managers; writers and artists; school and college teachers; professionals; homemakers; consultants; nonprofessional employees; entrepreneurs; students, nonorganizational role, and unknowns. 
We grouped newspapers into five categories according to their circulation scope, keeping our two Quebec-based papers separate. A noteworthy difference emerges in the percentage of journalists in the different news outlets. While they make up $64.5 \%$ of the overall sample, they write only $30 \%$ of Le Devoir's op-eds, compared to $67.5 \%$ in the National Post and 60.2\% in the Globe and Mail. Le Devoir makes up for this difference in the percentage of academics, and to a lesser extent politicians, think-tank staff, and public and private managers who publish op-eds. Most interesting for our purposes, however, is that while academics account for $8 \%$ of the total sample, in Le Devoir they make up $27.7 \%$. This perhaps points to the importance of academics in Quebec political life in the post-1960s era, and the general esteem in which intellectuals are held in French (and thus Québécois) culture. ${ }^{9}$ It also lends credence to the widespread perception of Le Devoir as more intellectually oriented than its French-language counterparts in Quebec and in the rest of Canada. This may be linked to the fact that it is the only mainstream news daily in Quebec, and one of the few in Canada, that is independently owned. The evidence we offer here certainly suggests that Le Devoir is closer to an intellectually oriented European model for newspapers than either the Globe and Mail or the National Post.

Professors' presence is also higher than the sample average in the Globe and Mail (12.6\%), perhaps suggesting the desire of the newspaper to appeal to a more elite and educated audience or the higher status associated with writing for the Globe. There are fewer academics writing for the National Post (9.1\%) than Le Devoir and The Globe and Mail, something not surprising given the antiacademic bent of National Post's neoconservatism and the left-liberal leanings of academics (Nakhaie and Brym 1999). If we remove journalists from the analysis (see Table 4), professors (bolded again for emphasis) make up $22.4 \%$ of the nonjournalist op-ed writers. This places professors almost neck and neck with the next largest category, consisting of labour unions, think tanks, and policy institute staff together with members or staff of advocacy organizations (20.2\% of the nonjournalist authors). Politicians and diplomats together make up $12.5 \%$ of the nonjournalists, just ahead of freelance writers and artists (11.2\%). Managers in the public and private sector make up $8 \%{ }^{10}$ while the rest of the sample is made up of several smaller categories.

In addition to occupation, another important variable to look at as we map the social space of opinion is national base of the authors. Canada is

9. For an important book that raises questions about the ways in which Anglo-American intellectuals see the French intellectual class, see Collini (2006).

10. These include a small number of university presidents and chancellors. 
Table 4: Occupation of Nonjournalist Op-ed Authors in 12 Canadian Newspapers

$\begin{array}{lcc}\text { Professors } \quad \text { Occupation } & \text { Frequency } & \text { Percent } \\ \text { Think tank, advocacy, union } & \mathbf{1 7 4} & \mathbf{2 2 . 4} \\ \text { Politicians and diplomats } & 157 & 20.2 \\ \text { Writers and artists } & 97 & 12.5 \\ \text { Managers (public and private sector) } & 87 & 11.2 \\ \text { Professionals } & 63 & 8.1 \\ \text { Nonprofessional employee } & 58 & 7.4 \\ \text { Consultants } & 23 & 2.9 \\ \text { Nonoccupational role } & 22 & 2.8 \\ \text { School and college teachers } & 22 & 2.8 \\ \text { Student } & 17 & 2.1 \\ \text { Other } & 11 & 1.4 \\ \text { Total } & 46 & 5.9 \\ \end{array}$

a relatively small nation that has been historically dominated culturally and economically by Great Britain and, more recently, the United States. This context makes us particularly interested in knowing more about the national origins of the op-ed writers in our sample. As it turns out, the vast majority (90.6\%) of authors in the overall sample resides in Canada; only 5\% hail from the US and 2.3\% from the UK. Despite the fears of Canadian nationalists, often justified, of the foreign domination of intellectual life here (Cormier 2004), the social space of opinion represented by op-eds in Canadian newspapers is solidly indigenous. ${ }^{11}$ While the cultural imprint of France, the first European power to establish a colonial presence in Canada, could be felt in Quebec for several centuries after its displacement by Britain, it does not supply op-ed authors to Quebec newspapers. This is seen in the low percentage of "other" national origins in the two Quebec newspapers in our sample, even lower than in the sample overall $(2.5 \%)$. Also absent from our op-ed pages, as this figure makes clear, are opinion-makers from other European countries, from the Americas more broadly, and from elsewhere in the developing world. ${ }^{12}$

11. Canadian sociologists have had some recent debate about questions of the British versus the American influence on, or dominance of, our intellectual life. Clearly we see more than twice as many American as British op-eds in our papers. This still suggests, however, a fair amount of British influence given the much larger American population and number of newspapers and columnists. Moreover, it would be strange if there were not more links with the US than with Britain, given the realities of geography, something that still matters even under globalization.

12. While we did not look specifically for Mexico or other Latin American countries for national origin, the data indicate that while our economic ties with our two major southern neighbours have become tighter in the past two decades, as yet there is no equivalent integration of citizen editorializing on issues of the day. 
Given the traditional dominance of men in the public sphere and fields of power in society, it is not surprising that, according to our data, op-ed writing in Canada is a strongly gendered forum of public communication. Male op-eds writers make up almost three-quarters of our sample (see Table 5).

Table 5. Occupation by Gender of Op-ed Authors in 12 Canadian Newspapers

\begin{tabular}{lclll} 
& Mccupation & Female & Unknown & Total \\
Journalists, columnists, broadcast- & 1038 & 396 & 4 & 1438 \\
ers & $72.2 \%$ & $27.5 \%$ & $0.3 \%$ & $100 \%$ \\
Professors & $\mathbf{1 4 4}$ & $\mathbf{2 7}$ & $\mathbf{3}$ & $\mathbf{1 7 4}$ \\
& $\mathbf{8 2 . 8 \%}$ & $\mathbf{1 5 . 5 \%}$ & $\mathbf{1 . 7 \%}$ & $\mathbf{1 0 0 . 0 \%}$ \\
Think tank, advocacy, union & 124 & 32 & 1 & 157 \\
& $79.0 \%$ & $20.4 \%$ & $.6 \%$ & $100.0 \%$ \\
Politicians and diplomats & 77 & 17 & 3 & 97 \\
& $79.4 \%$ & $17.5 \%$ & $3.1 \%$ & $100.0 \%$ \\
Writers and artists & 60 & 24 & 3 & 87 \\
Managers (public and private sec- & $69.0 \%$ & $27.6 \%$ & $3.4 \%$ & $100.0 \%$ \\
tor) & 49 & 12 & 2 & 63 \\
Professionals & $77.8 \%$ & $19.0 \%$ & $3.2 \%$ & $100.0 \%$ \\
& 42 & 15 & 1 & 58 \\
Blue collar and clerical employees & $72.4 \%$ & $25.9 \%$ & $1.7 \%$ & $100.0 \%$ \\
& 13 & 10 & 0 & 23 \\
Consultants & $56.5 \%$ & $43.5 \%$ & $.0 \%$ & $100.0 \%$ \\
& 18 & 4 & 0 & 22 \\
Nonoccupational role & $81.8 \%$ & $18.2 \%$ & $.0 \%$ & $100.0 \%$ \\
& 15 & 7 & 0 & 22 \\
School and college teachers & $68.2 \%$ & $31.8 \%$ & $.0 \%$ & $100.0 \%$ \\
Student & 9 & 7 & 1 & 17 \\
& $52.9 \%$ & $41.2 \%$ & $5.9 \%$ & $100.0 \%$ \\
Other & 6 & 4 & 1 & 11 \\
Total & $54.5 \%$ & $36.4 \%$ & $9.1 \%$ & $100.0 \%$ \\
& 18 & 28 & 0 & 46 \\
\hline
\end{tabular}

1. In some cases, the author's gender could not be determined because the author's full first name was not given.

It is worth noting that women's representation varies according to the authors' reported occupational status. While women make up $26.3 \%$ of our sample, and about the same percentage of the journalists, there is less gender parity in the more prestigious nonjournalist categories such as university professor, politician/diplomat, and writer/artist, and considerably more in the lower status roles such as school teacher, nonprofes- 
sional employee, nonorganizational role, and those whose status was not stated as one can see in Table 5. Even though the status competition from within the newspapers (between beat reporters) and from without (between free-lance writers and writers more generally) for the prestigious job of columnist is intense and dominated by men, it appears that woman do better in breaking the glass ceiling in journalism than they do in the academic profession when it comes to op-ed writing.

Turning to a more fine-tuned analysis of university professors themselves in the sample, ${ }^{13}$ Table 6 presents the broad breakdown of their academic fields or discipline groups. Again, we are interested in the extent to which the representation of the fields in the op-ed pages approximates their actual proportions in the Canadian professoriate. We know that the proportions of Canadian university professors are as follows: professional fields $27 \%$, the social sciences $25 \%$, the sciences $20 \%$, humanities $19.5 \%$, and business disciplines $7 \%$ (Canadian Association of University Teachers [CAUT] 2008a) ${ }^{14}$ As seen in Table 6, both the ordering and the proportions of the broad fields among op-ed writers differ in several ways from their representation in Canadian academia.

\section{Table 6: Academic Op-ed Authors by Faculties}

Broad Field

\begin{tabular}{lcc} 
Social science & $\mathbf{1 0 7}$ & $\mathbf{9 7 2 3}$ \\
& $\mathbf{6 1 . 5 \%}$ & $\mathbf{2 5 \%}$ \\
Professional & 30 & 10,305 \\
& $17.2 \%$ & $27 \%$ \\
Humanities & 28 & 7467 \\
& $16.1 \%$ & $19.5 \%$ \\
Business & 7 & 2709 \\
Science and math & $4.0 \%$ & $7 \%$ \\
\multirow{2}{*}{ Total } & 2 & 7800 \\
& $1.1 \%$ & $20 \%$ \\
\hline
\end{tabular}

Canadian Association of University

Teachers Data

305

467

2709

1. The CAUT data include an additional category of "unreported," with 294 cases.

13. Our unit of analysis, it should be noted, is the op-ed, not the professor. It is possible that some professors have authored more than one op-ed in our sample. However, since we are interested in the relative weight of discipline and gender rather than particular individuals, this does not detract from our analysis.

14. We regrouped CAUT's data to reflect as much as possible the categories we used in our coding. Social science in the CAUT figures excludes business and law, and includes education, a category that did not appear in our data. Professionals encompass all the healthcare occupations, as well as engineering, law, and architecture. Humanities includes the fine arts. The sciences encompass math and physical sciences as well as agricultural and biological sciences. 
Though we would expect professional faculty to dominate the writing of op-eds, given that they constitute the largest proportion of Canada's professoriate, social scientists are clearly the leaders in op-ed writing in our sample; social scientists make up $25 \%$ of Canadian professors but account for almost two-thirds of the op-ed authors. Professional faculty are our next largest category (17\%), a proportion that is nonetheless considerably smaller than their share of Canadian professors. Humanities (16\%) and business faculty (4\%) approximate their share of the faculty complement.

The most striking divergence is seen in the sciences. The third largest disciplinary grouping in Canadian universities, they barely register in the op-ed pages. This does not mean, of course, that scientists do not have a public presence. Obviously they do, as seen in such forums as Science, on TV shows, in lectures on science topics put on by universities, and in best-selling, or at least widely available books of popular science. There is even an academic journal that deals with the issue of science and the public called The Public Understanding of Science. Furthermore, a systematic content analysis of news articles would undoubtedly reveal that scientists, more often than scholars from other disciplines, are quoted as "expert" news sources. Whatever the reason, scientists tend not to write op-eds.

When we examine how the disciplinary groupings appear in specific newspapers, some interesting differences emerge, as seen in Table 7.15 One interesting contrast that emerges is that while the social sciences make up $61 \%$ of the academic writers overall, this proportion is con-

Table 7: Fields of Academic Op-ed Authors for Selected Newspapers

$\begin{array}{lccc}\text { Field } & \text { Globe and Mail } & \text { National Post } & \text { Le Devoir } \\ \text { Social science } & 15 & 12 & 13 \\ & 48.4 \% & 46.2 \% & 56.5 \% \\ \text { Professional } & 9 & 7 & 2 \\ & 29.0 \% & 26.9 \% & 8.7 \% \\ \text { Humanities } & 3 & 5 & 6 \\ & 9.7 \% & 19.2 \% & 26.1 \% \\ \text { Business } & 4 & 2 & 1 \\ & 12.9 \% & 7.7 \% & 4.3 \% \\ \text { Science and math } & 0 & 0 & 1 \\ & 0 \% & 0 \% & 4.3 \% \\ \text { Total } & 31 & 26 & 23 \\ & 100 \% & 100 \% & 100.0 \%\end{array}$

15. Given the small number of cases in some cells, our results are only suggestive of patterns in the gravitation of different news outlets toward particular kinds of academicauthored op-eds. We intend to do further research to increase the sample size among academics and address the methodological and quantitative questions that have to be addressed to say something more definitive. 
siderably lower in the two national newspapers, and even lower in $L e$ Devoir. ${ }^{16}$ There are also several interesting differences between Le Devoir and the two national English-language newspapers. Le Devoir has a larger percentage of social scientists and especially humanities scholars than the Globe and Mail and National Post. In fact, of all the newspapers in our sample, the humanities have their highest representation in $L e$ Devoir (26\%), more than twice their proportion in the Globe and Mail, and considerably higher than the average of the other newspapers in the sample $(16 \%)$.The presence of the humanities and social sciences may reflect the French pattern of public intellectual involvement dominated by disciplines such as sociology, literature, and philosophy. It may also reflect Le Devoir's status as the premier French-language newspaper of the Quebec nation within a nation, especially given the historical role that intellectuals and academics have played in disseminating nationalist sentiment in the province since the 1960s. The elite national newspapers in English Canada, in contrast, contain far more contributions from professional and (especially in the Globe and Mail) business faculties. Conversely, professional faculty make up $29 \%$ and $27 \%$ of the Globe and Post respectively, and only 9\% of Le Devoir's op-eds. Professionals are the second largest field in both the Globe and Mail and National Post. While the proportion of business faculty in Le Devoir (4\%) mirrors their presence in the broader sample, business scholars have a larger presence in the Globe and Mail (13\%) and the National Post (8\%).

When we disaggregate the data regarding the social sciences and humanities, it is clear that sociologists make far less use of the op-ed as a means of communicating with broader audiences than their colleagues in political science and economics, as we see in Table 8.

Political scientists, in fact, are the largest category of all the academic op-ed writers, and economists are the third largest after professional faculty. Historians follow closely behind the economists as the fourth largest group of op-ed writers in academe, and are more than twice as numerous as sociologists. Business faculty in Canada are represented in our data in the same proportion as sociology. ${ }^{17}$ Sociologists are also outnumbered by international development faculty. ${ }^{18}$ Our "other social

16. The social sciences have their highest representation in some of the smaller newspapers, for example, accounting for $95 \%$ of the 16 academic writers in the Calgary Herald, and $75 \%$ of the 12 academics in the Winnipeg Free Press.

17. An alternative categorization scheme that perhaps better reflects the weight of the business perspective in Canada's op-ed pages is to combine business and economics, based on the similarities in their overarching focus and frameworks. An economics-business category overtakes the professionals as the second largest group of op-ed writers, making up $18 \%$ of the sample. We thank Rick Helmes-Hayes for this insight.

18. For a discussion of op-ed writing within this field see Bishara (2004). 
Table 8: Academic Op-Ed Authors' Discipline in Combined Canadian Newspapers

\begin{tabular}{|c|c|c|}
\hline Discipline & Frequency & Percent \\
\hline Political science & 37 & 21.3 \\
\hline Professional & 30 & 17.2 \\
\hline Economics & 24 & 13.8 \\
\hline Other social science & 21 & 12.1 \\
\hline History & 18 & 10.3 \\
\hline Women's studies and other interdisciplinary programs & 10 & 5.7 \\
\hline Humanities & 10 & 5.7 \\
\hline International Development & 8 & 4.6 \\
\hline Sociology & 7 & 4.0 \\
\hline Business & 7 & 4.0 \\
\hline Science and math & 2 & 1.1 \\
\hline Total & 174 & 1000 \\
\hline
\end{tabular}

sciences" category encompasses several disciplines that are each represented by only one or two cases: psychology, criminology, policy studies, anthropology, geography, etc. Only two of the op-eds are authored by scholars in women's studies programs, and there are eight from other interdisciplinary programs (environmental, rural, native studies, etc.), a combined total essentially the same as sociology's representation. As with the broad academic fields, these data do not reflect the proportion of specific disciplines at Canadian universities. Most striking in this regard is the fact that political scientists and economists make up only $2.3 \%$ and $2.6 \%$, respectively, of Canadian university faculty (CAUT 2008a) while writing $21.3 \%$ and $13.8 \%$, respectively, of the academic op-eds.

There are a number of findings in Table 8 that seem counterintuitive. Given the expansion of criminology programs across the country, it is surprising that there are only two criminologist-authored op-eds in the sample. Part of the issue, of course, is the low number of criminologists in Canada relative to sociologists (108 compared to 1095). Given the public interest in crime-related topics, one might have thought there would be more criminologists operating in this genre than we found. We suspect that a news content analysis would reveal a much higher representation of academic criminology faculty who are cited as news sources in articles on crime and criminal justice policy than we see here. It also may be that criminologists' desire to remain "scientific," and distance themselves from a more ideological position often associated with sociology proper, explains the relatively low number of criminologists writing op-eds. Alternatively, the postmodern "critical" wing of Canadian criminology may be more skeptical of popular writing than more "old-fashioned" radical or liberal Canadian sociologists (Ericson 2006).

Since various academic disciplines are gendered in distinct ways, this is another factor worth consideration. As we have mentioned, there 
are fewer women among the academic authors than in the sample as a whole $-15.4 \%$ compared to $27 \% .{ }^{19}$ Women are also underrepresented in the op-ed pages compared to the gender ratio among Canadian academic faculty today, where women make up 32\% (CAUT 2008b). Our data also allows us to compare the variation in women's presence across disciplines in the op-ed pages with the gender ratios found in Canadian university fields and departments. According to recent data reported by CAUT (2008b), women make up $61.6 \%$ of faculty in health professions and occupations, $49 \%$ in education, $40 \%$ in the fine arts, $41 \%$ in humanities, $33.6 \%$ in the social sciences (this encompasses the law faculty where women make up 40\%), $27 \%$ in agricultural sciences, $14.6 \%$ in math and physical sciences, and $11.5 \%$ in engineering and applied sciences. Within these broad fields, of course, there are substantial differences in the gender composition of various disciplines. For example, within the social sciences, the percentage of women remains much lower in political science $(28.6 \%)$, business $(27.5 \%)$, and economics $(18 \%)$, than in sociology $(46.6 \%)$ and law $(40 \%)$.

In our op-ed data, the general patterns of women's presence across the disciplines are largely commensurate with this breakdown, even though the proportions of op-ed authors are lower in every field. Women are underrepresented in the op-ed pages in general relative to their proportion of Canadian academic faculty, as noted above. The disciplines with the highest percentage of women writing op-eds are the professional faculty, and women's studies and other interdisciplinary programs, where they comprise about a third of the authors. The next largest proportion of women is found in the business disciplines (about 25\%), and the humanities (14\%). The disciplines in which women have the lowest representation are sociology, political science, and the other social sciences (about $10 \%$ in each of these), and economics where there are no women authors. Given that sociology is one of the disciplines in which gender parity has advanced the furthest in academe, the low percentage of female sociologists in the op-ed pages is surprising. But with only seven cases in this category and similarly small numbers in several others, we cannot regard these patterns as representative of academic op-ed writing in Canada more generally. We would need a larger sample of op-eds authored by university faculty to understand the gender-discipline correlation to understand why women academics, irrespective of discipline, are underrepresented in op-ed writing in general. ${ }^{20}$

19. Academic women have increased their presence among op-ed writers over the fiveyear period encompassed by our data, rising from $12.6 \%$ in 1999 to $18.2 \%$ in 2004 .

20. As of 2004, women make up $19.3 \%$ of full professors in Canada, $35.2 \%$ of associate professors, and $40.9 \%$ at the assistant level (CAUT 2008b). We could speculate 
Any analysis of the relative presence of academic disciplines in the op-ed pages has to take account of major events in the broader environment. For example, in the weeks before and after an election campaign, the prevalence of the writings of scholars from particular specializations, especially political science, economics, and history, will be heightened by both supply and demand factors. That is, scholars from these disciplines are likely to be more motivated to disseminate their expert opinion on public issues during these periods, and newspaper editors more welcoming of essays by people with recognized expertise on the most pressing and topical matters that their outlets are covering. The 2004 national election year undoubtedly goes some way to explaining the increase in the relative proportion of political scientists compared to 1999. Indeed, only in 2004 do political scientists constitute the single largest category of op-ed writers (25.3\%). In 1999 they are the second most prevalent category (17.2\%) after the professional categories (19.5\%). However, the fact that even in 1999, political science is more highly represented than all other disciplines except the professionals - almost $4 \%$ higher than economics (12.6\%) and history (12.6\%), and fully $10 \%$ higher than sociology $(7 \%)$ - indicates that electoral seasons do not explain everything about the disciplinary variance in op-ed authorship. There are about 225 more sociologists than political scientists in Canada, with the two disciplines representing $11 \%$ and $8 \%$ of all social science faculty respectively (CAUT 2008a), which makes political scientists' greater presence in the op-ed pages all the more striking.

Institutional factors are also worth serious consideration. Professors in Canada are employed in relatively autonomous university institutions

that women's underrepresentation in the op-ed pages has to do with the lower average professional status of female academics, which is partly tied to the relatively recent increase in women's presence in academe. More women than men do not yet have tenure and/or have not advanced up the ranks from associate to full professor. At the same time, op-ed writing is not rewarded to the same degree as peer-reviewed publications and conferences when it comes to tenure and promotion; the recompense is in softer terms of status and perhaps fulfillment. Therefore women, more than men, need to focus their writing on realms that are academically and professionally recognized. Since newspapers are more exposed to market and political pressures than universities and the training time for an op-ed writing journalist is less than for a tenured professor with a $\mathrm{PhD}$, they both have the incentives and the ability to do more to improve the gender balance in their organizations. It is also possible that women who do endeavor to share their expertise beyond academic audiences choose activities that are more oriented to "thick" publics (research projects involving community groups come to mind, such as participatory action research), than to the "thin" publics exemplified by readers of mass print media. For a discussion of the relationship between gender, academic rank, and the quantity and type of publication output, see Nakhaie (2002). For an analysis of gender, rank, and discipline, see Nakhaie (2007). Finally, the gender ratio among faculty at different types of universities may play a role here since almost $60 \%$ of academic op-ed authors work at research-intensive universities (see below). 
that hire and tenure their faculty largely based on the peer-reviewed publishing they produce and the teaching they do. There are different types of university institutions, however, and the differences between research-intensive universities with graduate programs and teaching-oriented institutions focused on undergraduate students must be taken into account as we think about academics and their publics. The Canadian higher educational system is structured differently than the American system; we do not have the steep hierarchical divisions between state or city colleges and elite institutions such as Harvard and Yale, based on massive endowments and high and variable levels of tuition. Compared to the hierarchical American system, Canada's educational arrangements are relatively "flat" (Davies and Hammack 2005; McLaughlin 2005). There is a difference between the social structure of elite research universities like University of Toronto, McGill, and the University of British Columbia and more teaching-oriented schools such as St. Mary's, St. Thomas, and Trent, but these differences are not as great as between Harvard and the least prestigious universities in the United States. In addition, the American system has a range of elite-oriented and expensive high-status private liberal arts schools that do not (yet) exist in a significant way in Canada.

How is the writing of op-eds shaped by the institutional location of the university in which professors are employed? One could imagine that professors at teaching-intensive institutions write more op-eds than research-oriented faculty, since the pressures to produce peer-reviewed publications for tenure and promotion tend to be less onerous. One could also claim that the style of work one does everyday when teaching undergraduates is more similar to what one does when writing an op-ed than is writing for high-level, peer-reviewed publications and in teaching graduate students. Or, it may be that university professors at the more research-oriented institutions write more op-eds because their research skills and publishing records give them more original and credible things to say and because the status of the institutions they represent makes newspapers more willing to publish their op-eds. This is an empirical question that needs to be addressed in light of the representation of research- and teaching-intenstive universities in Canadian academe.

For the 174 professor-authored op-eds in the sample, we coded the universities with which they were affiliated at the time the op-ed was written. About $6 \%$ were universities outside of Canada, all but one of these in the US. We then recoded the Canadian universities based on the categorization scheme used by MacLeans magazine in its annual ranking of these institutions. ${ }^{21}$ Teaching-intensive institutions are represented

21. Not all universities participate in MacLeans annual ranking. With one exception, all the Canadian universities that appeared in our sample were also categorized by MacLeans. 
by the undergraduate category; these are universities that have few MA or $\mathrm{PhD}$ programs. Universities in the comprehensive category are more research-oriented and grant graduate degrees, including the PhD level. Medical-doctoral universities offer a wider range of $\mathrm{PhD}$ programs, and because they encompass medical schools, enjoy larger financial endowments.

Table 9 provides a breakdown of op-ed writing by institutional location. The table shows that of the op-eds authored by professors, almost two thirds come from the top tier, as it were - the medical-doctoral institutions. A further $27 \%$ are based at comprehensive universities. Only $6 \%$ of the op-eds are authored by professors at teaching-intensive universities. When we exclude the non-Canadian cases, fully two-thirds come from top tier institutions, and a further $30 \%$ from comprehensive institutions. This pattern varies little across the major types of newspapers (table not shown). A notable exception in this regard is the Montreal Gazette where $81 \%$ of its academic op-ed authors are employed at medical-doctoral institiutions, only $12 \%$ at comprehensive universities, and none at undergraduate universities. This mainly reflects the strong presence of McGill University in the Gazette's op-ed pages, a phenomenon we will discuss below.

\section{Table 9 Academic Op-ed Authors by Type of University}

$\begin{array}{lcc}\quad \text { Type of Institution } & \text { Frequency } & \text { Percent } \\ \text { Medical-doctoral } & 104 & 59.7 \\ \text { Comprehensive } & 47 & 27 \\ \text { Undergraduate } & 10 & 5.7 \\ \text { American } & 11 & 6.3 \\ \text { Foreign } & 2 & 0.1 \\ \text { Total } & 174 & 100.0\end{array}$

The data shown in Table 9 diverge little from the actual proportions that each tier represents within Canadian academe. According to recent data from CAUT (2008a), 60\% of Canadian faculty are employed at medical-doctoral institutions, $24.1 \%$ at comprehensive universities, and $15.7 \%$ at undergraduate-oriented universities. But taking into account that the 11 US faculty in our sample are all from top tier US schools, the percentage of authors at medical-doctoral institutions rises to $66 \%$, making them slightly overrepresented relative to faculty numbers in Canada. At the same time, professors at teaching-oriented Canadian universities are somewhat underrepresented in the op-ed pages. On the whole, then, the data suggest that faculty at undergraduate-focused institutions are

The exception, l'Université de Québec a Montréal (UQAM), we categorized as comprehensive. 
at a slight disadvantage compared to those employed at more researchoriented institutions when it comes to appearing in the op-ed pages. The extent to which this reflects the incentive structures, time constraints, and other factors within these universities, as well as the selection criteria of news editors, is a question for further research.

Our analysis also points to the relative influence of specific Canadian universities in the op-ed pages. McGill provides the largest percentage $(17.8 \%)$ of op-eds, followed by the University of Calgary $(9.8 \%)$ and the University of Toronto $(6.3 \%)$. All three are medical-doctoral institutions. Only one of the institutions that appears among the top five in op-ed authorship, Simon Fraser, belongs to the comprehensive category. ${ }^{22}$ As to why McGill University faculty appear so much more often than other top tier schools, we suspect it has something to do with geography, language, and to some extent, politics. Obviously, there is a mutual affinity between newspapers and academic authors in the same city or province - academics tend to write op-eds for papers in their own city and region of the country. This is seen, for example, in the fact that $76.5 \%$ of University of Calgary op-ed writers appear in the Calgary Herald. Looking at this relationship another way, in terms of the weight of specific universities within each newspaper, $81.2 \%$ of the academic-authored op-eds in the Calgary Herald come out of the University of Calgary, compared to only $7 \%$ in the two national newspapers. Of McGill-authored op-eds, 65.6\% appear in the Montreal Gazette. Again, looking at this as the percentage of each university within each newspaper, $84 \%$ of the Montreal Gazette's academic-authored op-eds come from McGill, compared to $12 \%$ of the two national newspapers.

Geographic affinity does not fully explain why McGill's proportion in the Montreal Gazette is so much higher than other top tier universities' presence in similarly located large newspapers; McGill dominates the Gazette's academic-authored op-eds even more than the University of Calgary dominates the Calgary Herald. Nor does geographic proximity alone account for the large presence of McGill among the academicauthored op-eds in general $(17.8 \%)$ compared to the University of Toronto $(6.3 \%)$. Indeed, McGill's presence in the op-ed pages of the two national newspapers which are both based in Toronto $(12.3 \%)$, is not that far behind the University of Toronto (17.5\%).

We suspect that a combination of language and politics plays a role here. Quebec's internal politics, and its interaction with the federal and

22. We must emphasize that our sample does not allow us to claim which universities in Canada have faculty who write more or fewer op-eds. For practical reasons, we gathered data from selected newspapers; if we had included the Saskatoon, Hamilton, Regina, Ottawa, Quebec City, St. John's, London, and Charlottetown papers, the results might have been different. 
other provincial governments, hold enormous, nation-wide importance as a news topic in Canada. For editors of national newspapers seeking or considering English-language expert opinion on these issues, op-eds written by Anglophone scholars based in Quebec have an obvious value. McGill, as a top tier school, would hold as much or more appeal to these newspapers as scholars from a Toronto-based research-intensive university. The same is true of the most important English-language daily in Quebec, the Montreal Gazette. This partly explains why McGill makes up $84 \%$ of the academic op-eds in the Gazette but only $8.7 \%$ in Le Devoir. Language explains why l'Université du Montréal appears only once as the institutional base of the 25 academic op-eds in the Montreal Gazette, compared to 21 op-eds by McGill scholars in this newspaper. A content analysis of op-eds by scholars, which is beyond the scope of this paper, could discern whether Quebec politics is a common focus of the pieces by McGill faculty. Given these results, it may also be worth exploring the internal culture of McGill to see if there are distinctions between how various research universities see their role in promoting broad intellectual debate as opposed to narrower academic peer-reviewed scholarship (for a discussion of the early history of McGill University sociology, see Shore 1987).

\section{Conclusions: Sociology and the Op-Ed in Canada}

Our preliminary map of the space of opinion in Canada using the oped as an indicator has allowed us to talk about a number of tendencies and patterns. More empirical research, however, is required to develop a fuller analysis of opinion formation and the role of sociologists in this process. We conclude by first laying out some ideas for further empirical research that would help sociologists construct a better picture of the relationship between academics, sociologists, and public opinion formation through studying the writing and reading of op-eds. Moving beyond this important but narrower academic agenda, we also offer some more speculative and normative thoughts regarding the question of the oped and Canadian sociology in relation to the larger debate stimulated by Michael Burawoy and the increasingly global debate about public sociology.

While we have analyzed a sizeable data-set, a larger sample of academic op-eds, a longitudinal design, and the use of multivariate statistical methods would allow a more systematic look at the patterns we have examined here. Examining a greater number of op-eds by academics would permit more reliable observations as to who writes them. Content 
analysis would allow us to examine the claims they make (for a model for content analysis of op-eds, see Jacobs and Townsley forthcoming). In addition, while we have speculated about some of the reasons for the patterns we found, a closer look at both the internal dynamics of newspapers (for example, decision-making about which op-eds are accepted or solicited) and within universities (what incentives exist for writing op-eds, what training and support do scholars receive in their distinct disciplines and universities?) would say something more definitive about both the pushes and the pulls that determine the rate of op-ed writing by academics, by sociologists, by women, and by scholars situated in different institutional contexts. What do universities (for example, the public relations offices and deans), and national funding institutions (SSHRC, in particular, in the social sciences and humanities), do to encourage more public engagement on the part of academics, and how well are their efforts succeeding? What potential role do campus-based research institutes play in promoting public writing and encouraging faculty to engage in public intellectual debate and dialogue based on expert knowledge?

In addition to these institutional issues, there are also important questions to ask about the content of the op-eds. If op-ed writing is a way for academics to communicate their discipline-specific scholarly knowledge to a wider audience, then how are sociologists utilizing this space? Are they presenting the findings of their scientific research, or are they making moral and normative claims? How does this look in comparative context in light of the ways other disciplines communicate to the public? From our perspective, Burawoy's discussion of the public academic work of other disciplines tends to be excessively polemical and sociology-centred. These kinds of questions require a more detailed content analysis of op-eds, something we are in the process of undertaking in the Canadian context, following the research design developed by Jacobs and Townsley (forthcoming) for their research on the social space of opinion in the United States.

This research agenda requires more conceptual clarity as well as more empirical research. This is particularly true with regards to the distinction Burawoy draws between "organic" and "traditional" public sociologists (Burawoy 2004a). To discern whether op-eds by sociologists and other social scientists represent organic public intellectual work based on engagement with social movements, grassroots organizations, or local communities - or whether they represent a traditional intervention aimed at the well-educated readers of prestigious national newspapers, requires a more detailed examination of specific op-eds and their reception. As we emphasized above, this is something we have not done here but could usefully explore in the future. Much more could be said, 
furthermore, regarding the claims we have implicitly made regarding regional, economic, and social structural bases for the patterns we found in op-ed writing, as well as the internal culture of specific newspapers (the Globe and Mail, versus Le Devoir or National Post, for example). We will put some of these issues in international comparative context as part of a research team in the United States, Australia, and Canada led by Jacobs and Townsley.

Over and above the important theoretical and empirical questions that could be addressed by further study of the op-ed in Canada and beyond, there is also a range of normative questions worth considering in light of the public sociology debate. Clearly, it would be impossible for Canadian sociologists to dominate the social space of opinion formation represented by the op-ed given the nature of the academic and journalistic fields. We think it would be possible, however, for Canadian sociologists to contribute as often as our colleagues in economics, history, political science, and professional (law, medicine and engineering) schools to op-ed writing if we were to make this more of a disciplinary priority.

The inherent nature of the disciplines of history, political science, and professional schools, we suggest, partly explains the patterns we found. Political scientists and historians, for example, have a natural advantage in terms of being experts on electoral politics, political leaders, and the history of our nation, subjects for which there is a natural "market" for opinions in news media outlets. The same is true for the expert knowledge and status possessed by economists, legal scholars, and experts based in medical schools and the health sciences.

Nonetheless, Canadian sociologists possess a wealth of knowledge regarding political sociology, social movements, the historical sociology of Canada, and policy-relevant questions related to the family, gender, poverty, crime, education, and inequality. If Canadian sociologists put their minds to this, they could, we believe, increase our profile in the social space of opinion by changing aspects of our training, professional practice, and priorities. Just as the American Sociological Association set up a task force partly to recommend incentives for more public sociology, Canadian sociologists and their association could debate these issues and think through practical ways to emphasize and reward more involvement in public debate and dialogue.

With regard to the recognition of public academic work, we are already seeing a push by social science administrators to make sociology, geography, and other related disciplines more publicly oriented and accessible. Some faculty may understandably regard this emerging pillar of university strategic planning as evidence of bottom-line concerns to obtain more funding through establishing new constituencies or cli- 
ent bases within our local community, filling in the shortfall left by the steady decline in government resources and part of a trend asking faculty to do more with less. There is a big difference, it should be emphasized, between the kind of politically progressive, even left-wing public sociology we understand Burawoy to be promoting, and what many administrators would have in mind if they asked faculty to give talks in local high schools to raise the university's profile. We should not ignore, moreover, the extent to which moves towards more public relevance on our campuses are part of a growing manifestation of the university's drive to increase enrollments and hence revenue, and broader changes in the institutional mission of the university (Stevens, Armstrong and Arum 2008).

If public relevance is indeed an emerging priority of university administrators, it may provide sociologists and other academic faculty an opportunity to demand a shift in the incentive structure for the different types of work that we perform. These broader social forces must be treated with care - and a certain level of skepticism - but they could legitimize the call for greater recognition of public intellectual work in all its forms, including, but not only, op-ed writing. If universities acknowledge op-ed writing and other kinds of media work as ways of fulfilling a public relevancy mandate, it is logical for them to provide faculty with more preparation and training by public relations and communications professionals. Furthermore, the Canadian government, through SSHRC, could be encouraged to fund more projects to allow social scientists to reach broader publics than the recent priority of business audiences, allowing Canadian academics to retain intellectual control over their research agendas and results. To some extent this has happened at SSHRC in the past few years, with calls for its transition from research council to "knowledge council," as well as a growing emphasis on "knowledge transfer" in the granting process (SSHRC 2005). We believe, however, it would be useful not only to sharpen our critical understanding of these issues in relation to the public sociology debate in Canada, but also to undertake a deep and broadly participatory discussion of the specific forms of public academic work to be encouraged, as we have done here with the op-ed.

Prior to the question about how we would make this kind of change in our professional practice if we so choose, we should think carefully about the issue of whether we should make writing op-eds an activity that is more valued and emphasized. Should Canadian academics, in general, and sociologists in particular, spend a significant amount of their time and energy engaging with the public through op-eds? Will this have real influence on public opinion about the vital social and political 
issues we research and write about? Will it have a positive impact on Canadians' understanding and appreciation of our discipline? Can we control how our ideas are used, within the journalistic field, or are we setting ourselves up to be used by policy makers and politicians to justify decisions made for other reasons ${ }^{23}$

There is also the question of whether print media forums such as newspaper op-eds provide the best outlet for public sociology intervention given the opportunities represented by electronic blogs and the internet. ${ }^{24}$ If sociologists were to undertake efforts to improve our op-ed writing, it could be argued that we are getting there when the party is over, as a new wired culture pushes newspapers into economic decline and erodes their influence on public opinion. Though addressing the debate about print media relevance is beyond the scope of this paper, we suspect that newspapers and traditional op-eds still retain influence in the broader culture even if their relationship with online media is changing dramatically (Bucy 2003).

More fundamentally, one could argue that sociology's relatively weak institutionalization in the Canadian context means that the first priority for the discipline must be the creation of a stronger and more professionalized research tradition similar to that of US sociology. This could be undermined by a serious focus on writing op-eds and other forms of public sociology (appearing on TV, giving public lectures, writing popular books and articles; see Davies; Goldberg and Van den Berg in this volume, as well as McLaughlin 2005). The "going professional" path $^{25}$ does not necessarily mean that sociologists would give up on public debate and policy sociology. A more professional sociology focused on rigorous research and training could well gain more academic appointments for sociologists over time, and thus increase the visibility of the discipline in the space of public opinion by following a model closer to economics (based on peer-reviewed articles) or history (high quality book publishing). The proponents of "professional not public sociology" could also well argue that the relatively low presence of sociology in the social space of opinion in Canada represented by op-eds flows from the oppositional, subcultural leftism within elements of the discipline (Davies, in this volume).

23. For a useful discussion of how public and/or policy sociology can lead to results that are beyond the control of the researcher, see Stacey (2007).

24. The importance of internet news and editorializing in shaping political activism and electoral outcomes was dramatically illustrated in Barack Obama's Presidential victory of November 2008. Several analysts point out that progressive blogging played a crucial role in the success of Obama's campaign (Ratcliff, 2008).

25. This phrase comes from a presentation by Scott Davies at McMaster in a forum on public sociology in Canada. 
Another possible perspective, however, is that efforts to participate on a level playing field with professional, or if one prefers, mainstream American sociology in terms of publishing ASA-style articles and technical and theoretically driven scholarship is a project doomed to failure. One could argue that the relatively "common sense" epistemology and traditional methodology of Canadian historians, the positivist, even scientistic orientation of Canadian economics and the links between political science and the Canadian state go a long way toward explaining their higher profile in the space of public opinion in our nation relative to the more methodologically diverse and politically radical culture of Canadian sociology (Gagnon 1987). From this perspective, while the strong currents of Marxism and feminism in Canadian sociology may help explain its relative marginalization in mainstream political dialogue, these traits of the discipline are arguably a cause for pride and celebration, not collective self-reproach (see Eichler 2001; Creese, McLaren and Pulkingham; Byrm and Nakhaie; Helmes-Hayes all in this volume; see Acker 2005 for this discussion in the American context).

These are big questions, obviously beyond the scope of this or any research design. The public sociology debate, in the context of Canada, represents one of the most important and interesting, albeit controversial topics for discussion within our discipline. We hope that it will be undertaken with an eye towards research findings and empirical evidence. It will be particularly important to conduct research, as we have done here, that disaggregates various genres of public interventions that represent options for academics interested in reaching broader publics. In this light, we believe we have moved the conversation forward by laying out the first map of the op-ed opinion space in Canada, contributing, we hope, to both the debate on public sociology in Canada and the broader debate about academics and their publics.

\section{REFERENCES}

Acker, Joan. 2005. Comments on Burawoy on public sociology. Critical Sociology $31(3): 321-31$.

Bishara, Marwan. 2004. Writing international development: The op-ed page. Signs 29(2):564-69.

Bourdieu, Pierre. 2005. The political field, the social science field and the journalistic field. Pp. 29-47 in Rodney Benson and Erik Neveu, eds., Bourdieu and the Journalistic Field. Cambridge: Polity Press.

Boyns, David and Jesse Fletcher. 2005. Reflections on public sociology: Public relations, disciplinary identity, and the strong program in professional sociology. The American Sociologist 36(3-4):5-26. 
Brym, Robert and John Myles. 1989. Social science intellectuals and public issues in English Canada. University of Toronto Quarterly 58(4):442-51.

Bucy, Erik P. 2003. Media credibility reconsidered: Synergy effects between onair and on-line news. Journalism and Mass Communication Quarterly 80(2):247-264.

Burawoy, M. 2004a. Public sociologies: Contradictions, dilemmas, and possibilities. Social Forces 82(4):1-16.

2004b. Introduction to "Public sociologies: A symposium from Boston College." Social Problems 51(1):103-106.

2005a. For public sociology. American Sociological Review 70(1):4-28. 2005b. The return of the repressed: Recovering the public face of U.S. sociology, one hundred years on. Annals of the American Academy of Political and Social Science 600:68-85.

2005c. The critical turn to public sociology. Critical Sociology 31(3):313-26.

2005d. Rejoinder: Towards a critical public sociology. Critical Sociology 31(3):379-90.

Canadian Association of University Teachers (CAUT). 2008a. Almanac of postsecondary education 2008-2009. http://www.caut.ca/uploads/2008 2 Staff.pdf. Accessed November 12, 2008.

2008b. CAUT equity review: Narrowing the gap: Women academics in Canadian universities. http://www.caut.ca/uploads/EquityReview2-en. pdf. Accessed November 17, 2008.

Clemens, Elisabeth, Walter Powell, Kris Mcllwane, and Dina Okamoto. 1995. Careers in print: Books, journals, and scholarly reputations. American Journal of Sociology 101(2):443-94.

Collini, Stefan. 2006. Absent Minds: Intellectuals in Britain. Oxford: Oxford University Press.

Cormier, Jeffrey. 2004. The Canadianization Movement: Emergence, Survival and Success. Toronto: University of Toronto Press.

Coser, Lewis. 1965. Men of Ideas, New York: Basic Books.

Coser, Lewis, Charles Kadushin, and Walter Powell. 1982. Books: The Culture and Commerce of Publishing. New York: Basic Books.

Davies, Scott and Floyd M. Hammack. 2005. The channeling of student competition in higher education: Comparing Canada and the United States. Journal of Higher Education 76(1):27-41.

Eichler, Margrit. 2001. Women pioneers in Canadian sociology: The effects of a politics of gender and a politics of knowledge. Canadian Journal of Sociology 26(3):375-493.

Ericson, Richard. 2005. Publicizing sociology. British Journal of Sociology 56(3):365-72.

Gagnon, Alain G. 1987. Intellectuals in Liberal Democracies: Political Influence and Social Involvement. New York: Prager. 
Jacobs, Ronald. Forthcoming. 2009. Culture, the public sphere, and media sociology: A search for a classical founder in the work of Robert Park. The American Sociologist.

Jacobs, Ronald and Eleanor Townsley. 2004. Media intellectuals and public sociology: The case of op-eds in the New York Times. American Sociological Association, San Francisco.

Book manuscript. Media Intellectuals and the Social Space of Opinion.

Massolin, Philip. 2001. Canadian Intellectuals: The Tory Tradition and the Challenge of Modernity, 1939-1970. Toronto: University of Toronto Press.

McLaughlin, Neil. 2005. Canada's impossible science: Historical and institutional origins of the coming crisis in Anglo-Canadian sociology. Canadian Journal of Sociology 30(1):1-40.

McLaughlin, Neil and Kerry Turcotte. 2007. The trouble with Burawoy: An analytic, synthetic alternative. Sociology 41(5):813-28.

McLaughlin, Neil, Lisa Kowalchuk, and Kerry Turcotte. 2006. Why sociology does not need to be saved: Analytic reflections on public sociologies. The American Sociologist 36(3-4):133-151. 2004. A Canadian rejoinder: Sociology north and south of the border. The American Sociologist. 35(1):80-101.

Myles, John. 2002. Where have all the sociologists gone? Explaining economics inequality. Canadian Journal of Sociology 28(4):551-59.

Nakhaie, M. Reza. 2002. Gender differences in publication among university professors in Canada. Canadian Review of Sociology and Anthropology 39(2):151-80. 2007. Universalism, ascription and academic rank: Canadian professors, 1987-2000. Canadian Review of Sociology and Anthropology 44(3):361-86.

Nakhaie, M. Reza and Robert J. Brym. 1999. The political attitudes of Canadian professors. Canadian Journal of Sociology 24(3):329-53.

Neuman, Lawrence. 2006. Social Research Methods: Qualitative and Quantitative Approaches. New York: Pearson.

Nikolaev, Alexander and Douglas Porpora. 2007. Talking war: How elite U.S. newspaper editorials and opinion pieces debated the attack on Iraq. Sociological Focus 40(1):6-25.

Nock, David A. 2000. Careers in print: Canadian sociological books and their wider impact, 1975-1992. Canadian Journal of Sociology 26(3):469-85. 1999. Star wars: Aspects of the social construction of citations in AngloCanadian sociology. The Canadian Review of Sociology and Anthropology 29(3):346-61.

Ratcliff, John. 2008. Politicking in the blogosphere. Contexts 7(4)70-72. 
Riffe, Daniel, Stephen Lacy, and Frederic Fico. 1998. Analysing Media Messages: Using Quantitative Content Analysis in Research. Mahwah, NJ: Lawrence Erlbaum.

Schiller, Dan. 1981 . Objectivity and the News. The Public and the Rise of Commercial Journalism. Philadelphia: University of Pennsylvania Press.

Schudson, Michael. 1978. Discovering the News. New York: Basic Books. 2005. Autonomy from what?" Pp. 214-223 in Rodney Benson and Erik Neveu, eds., Bourdieu and the Journalistic Field. Cambridge: Polity Press.

Shore, Marlene. 1987. The Science of Social Redemption: McGill, The Chicago School, and the Origins of Social Research in Canada. Toronto: University of Toronto Press.

Social Sciences and Humanities Research Council of Canada. 2005. From granting council to knowledge council: Renewing the social sciences and humanities in Canada. Volume 1: Ottawa.

Stacy, Judith. 2007. If I were the goddess of sociological things. Pp. 91-100 in Dan Clawson, Robert Zussman, Joya Misra, Naomi Gerstel, Randall Stokes, Douglas L. Anderton, and Michael Burawoy, eds., Fifteen Imminent Sociologists Debate Politics and the Profession in the TwentyFirst Century. Berkeley and Los Angeles, University of California Press.

Starr, Paul. 2004. The Creation of the Media: Political Origins of Modern Communications. New York: Basic Books.

Stevens, Mitchell, Elizabeth Armstrong and Richard Arum. 2008. Sieve, incubator, temple, hub: Empirical and theoretical advances in the sociology of higher education. Annual Review of Sociology 34:127-152.

Swartz, David L. 2000. From critical sociology to public intellectual: Pierre Bourdieu and politics. Theory and Society 32(5-6):791-823.

Townsley, Eleanor. 2005. The public intellectual trope in the United States. The American Sociologist 37(3):39-66.

Turner, Jonathon. 2005. Is public sociology such a good idea? The American Sociologist 36(3-4):27-45.

Winter, Elke. 2007. Neither 'America' nor 'Quebec': Constructing the Canadian multicultural nation. Nations and Nationalism 13(3):481-503.

Yagcioglu, Semiramis and Aysen Cem-Deger. 2001. Logos or mythos: (De)legitimation strategies in confrontational discourses of sociocultural ethos. Discourse and Society 12(6):817-852.

Lisa Kowalchuk teaches sociology at the University of Guelph. In addition to her research with Neil McLaughlin on public intellectuals in Canada, she has written on rural and urban social movements in El Salvador. She is beginning a three-year SSHRC-funded project comparing Central American doctors' and nurses' unions for their efforts to influence health-care policy. lkowalch@ uoguelph.ca 
Neil McLaughlin is an associate professor in sociology at McMaster University, where he teaches sociological theory. His research interests are in the sociology of knowledge and ideas. His most recent publications include "Collaborative Circles and Their Discontents: Revisiting Conflict and Creativity in Frankfurt School Critical Theory," in Sociologica 2/2008; "Global Public Intellectuals, Autonomy and Culture: Reflections Inspired by the Death of Edward Said" in Cultural Autonomy: Frictions and Connections, Petra Rethmann, Imre Szeman, and William D. Coleman, editors. Vancouver: University of British Columbia Press, (in press); and (with Skaidra Trilupaityte) "The International Circulation of Attacks and the Reputational Consequences of Local Context: Scapegoating Soros in Russia, Post-Soviet Lithuania and the United States, 2005-2006" (forthcoming Cultural Sociology).nmclaugh@mcmaster.ca 